\title{
Diseminasi (Promulgation) atau Penyebarluasan Rancangan Peraturan Daerah Anggaran Pendapatan dan Belanja Daerah (APBD)
}

\author{
Abdul Rais Asmar 1 * \\ ${ }^{1}$ Universitas Islam Negeri Alauddin Makassar. Jl. Sultan Alauddin No.63, Kec. Somba Opu, Kab. \\ Gowa, Sulawesi Selatan, Indonesia. \\ * Korespondensi Penulis. E-mail: rais.asmar@uin-alauddin.ac.id
}

\begin{abstract}
Abstrak
Rancangan peraturan daerah (ranperda) yang disusun pada tahap perencanaan perlu untuk disebarluaskan sebagai bentuk keterbukaan sehingga membuka pintu partisipasi masyarakat utamanya perda strategis seperti APBD. Tulisan ini mencoba mendeskripsikan secara kualitatif melalui pendekatan perundang-undangan (statutory approach) terhadap permasalahan penyebarluasan ranperda APBD. Berdasarkan beberapa sampel praktik penyebarluasan perda dan ranperda di beberapa daerah provinsi/kabupaten/kota di Indonesia terdapat perbedaan medote tetapi relatif masih sesuai dengan ketentuan perundang-undangan. Akan tetapi, penyebarluasaannya lebih pada saat perda telah ditetapkan. Adapun pada tahap perencanaan tidak terdapat gambaran yang jelas. Hal ini disebabkan oleh ketidaktegasan aturan perundang-undangan terkait penyebarluasan rancangan perda khususnya perda strategis seperti APBD.
\end{abstract}

Kata Kunci: penyebarluasan, ranperda APBD

\section{Reconstruction of the Philosophy of Paradigm of Science: Critical Study of Law as a Science}

\begin{abstract}
The draft local regulation (ranperda) compiled at the planning stage needs to be disseminated as a form of openness so as to open the door for community participation, especially strategic regional regulations such as APBD. This paper tries to describe qualitatively through a statutory approach to the problem of spreading the regional budget. Based on a number of samples of the practice of disseminating local regulations and regional regulations in several provices/regencies/cities in Indonesia, there are differences in meditations but are still relatively in accordance with statutory provisions. However, the spread was more when the local regulation was stipulated. As for the planning stage there is no clear picture. This is cause by the indecisiveness of the laws and regulations related to the dissemination of draft regulations, especially strategic regulations such as the regional budget.
\end{abstract}

Keywords: dissemination, regional budget regulation 


\section{PENDAHULUAN}

Produk peraturan perundang-undangan dalam konteks Negara Kesatuan Republik Indonesia dapat dibagi atas produk peraturan pusat dan daerah. ${ }^{1}$ Selanjutnya produk peraturan daerah itu sendiri melibatkan dua entitas pemerintahan yaitu pemerintah daerah provinsi dan pemerintah daerah kabupaten/kota. ${ }^{2}$ Berdasarkan hierarki dan aturan perundang-undangan produk peraturan daerah tersebut terdiri atas peraturan daerah provinsi, peraturan gubernur, peraturan daerah kabupaten/kota, peraturan bupati/walikota, dan peraturan kebijakan lainnya yang dikeluarkan oleh gubernur/bupati/walikota selaku kepala daerah. ${ }^{3}$

Kualitas produk peraturan daerah yang dibentuk sangat tergantung pada pemahaman perancang peraturan yang mendalam terhadap persoalan yang dihadapi dan kemampuan teknis yang memadai. Selain itu, yang tidak kalah penting adalah rangkaian tahapan pembentukan peraturan daerah yang prosesnya tidak gampang. Masing-masing tahapan menentukan terciptanya produk hukum yang baik. Dalam rangka tertib administrasi dan peningkatan kualitas produk hukum daerah, diperlukan suatu proses atau prosedur penyusunan Perda agar lebih terarah dan terkoordinasi. Dalam hal ini yang akan ditinjau adalah tahapan pembentukan peraturan daerah (perda). Hal ini disebabkan dalam pembentukan Perda perlu adanya persiapan yang matang dan mendalam, seperti pemberian masukan dari masyarakat atau wakil dari masyarakat agar terpenuhi unsur peran serta masyarakat dalam pembentukan perda. ${ }^{4}$ Salah satu tahapan yang penting dalam pembentukan perda adalah penyebarluasannya utamanya pada saat perda masih dalam rancangan karena dengan peningkatan upaya penyebarluasan perda pada saat perda masih berbentuk rancangan dapat meningkatkan transparansi dan partisipasi masyarakat. ${ }^{5}$

Umumnya proses pembentukan peraturan daerah provinsi/kabupaten/kota ditempuh melalui beberapa tahapan dan dibahas bersama antara DPRD dan kepala daerah. Pasal 20 ayat (1) UndangUndang Dasar Negara Republik Indonesia 1945 (UUD NRI 1945) menyatakan bahwa kewenangan membentuk undang-undang ada pada DPR dengan persetujuan Presiden. ${ }^{6}$ Kewenangan pembentukan itu secara mutatis mutandis berlaku pada penyerahan kewenangan pembentukan peraturan daerah kepada DPRD dan Kepala daerah. Baik DPRD/anggota DPRD maupun kepala daerah dapat menggunakan hak inisiatifnya untuk mengajukan rancangan peraturan daerah (Raperda) untuk dibahas dan diputuskan bersama di rapat paripurna. Mekanisme pembahasan peraturan daerah lebih lanjut diatur melalui tata tertib DPRD masing-masing daerah.

Salah satu rancangan perda yang penting bagi daerah adalah rancangan perda Anggaran Pendapatan dan Belanja Daerah (APBD) guna melaksanakan fungsi utama pemerintah daerah yaitu anggaran. Perencanaan pengelolaan keuangan daerah diatur melalui peraturan derah setiap tahun dalam bentuk APBD. mekanisme pembentukan peraturan daerah Anggaran Pendapatan dan Belanja Daerah (RAPBD) dimulai dari tahap perencanaan melalui program legislasi daerah (prolegda) agar prosedur pembetukannya berjalan secara terencana melalui suatu Program Legislasi Daerah (prolegda). Pasal 1 angka 1 UU No. 15 Tahun 2019 tentang Pembentukan Peraturan Perundangundangan (UU P4) yang menyatakan prolegda adalah instrumen perencanaan program pembentukan Peraturan Daerah Provinsi atau Peraturan Daerah Kabupaten/Kota. yang disusun secara terencana,

${ }^{1}$ Kesimpulan dari pemikiran Hans Kelsen dan Hans Nawiyaski bahwa struktur daripada norma-norma itu dibangun secara berjenjang dan berlapis-lapis, dalam arti suatu norma itu berlaku, bersumber dan berdasar pada norma yang ada di atasnya. Lihat Sulaiman, King Faisal, Teori Peraturan dan Perundang-undangan dan Aspek Pengujiannya, Yogyakarta: Thafa Media, 2017., hlm. 17

${ }^{2}$ Undang-Undang Negara Republik Indonesia Nomor 12 Tahun 2011 tentang Pembentukan Peraturan Perundang-undangan menempatkan kedudukan Perda sebagai produk hukum yang paling rendah tingkatannya dalam skema hierarki peratudan perundang-undangan.

${ }^{3}$ Priyanto, I Made Dedy, Kewenangan Gubernur dalam Pembatalan Perda Kabupaten Tabanan, Jurnal Advokasi FH Universitas Mahasaraswati Denpasar, Vol. I, Nomor 1, Tahun 2011., hlm 14.

4 Ronald M. M. Goni, Kewenagan Gubernur dalam Pembentukan Peraturan Daerah Sebagai Implementasi Pemberlakuan Otonomi Daerah, Jurnal Lex Administratum, Vol III, Nomor 4 Juni 2015., hlm.28

${ }^{5}$ Sugiarto, Anton Hutomo, Arti Penting Program Legislasi Daerah Bagi Pencapaian Tujuan Otonimi Daerah, Jurnal Justicepro FH Universitas Yos Soedarso, Vol. 06, Nomor 2, Tahun 2018., hlm. 13.

${ }^{6}$ Lihat juga Pasal 5 ayat (1) Undang-Undang Dasar Negara Republik Indonesia Tahun 1945 bahwa "Presiden berhak mengajukan rancangan undang-undang kepada Dewan Perwakilan. 
terpadu, dan sistematis.Selanjutnya Peraturan Menteri Dalam Negeri Nomor 16 Tahun 2006 tentang Prosedur Penyusunan Produk Hukum Daerah pada Pasal 4 dinyatakan bahwa penyusunan produk hukum daerah yang bersifat pengaturan dilaksanakan berdasarkan prolegda. Oleh karena itu, rancangan peraturan daerah APBD termasuk prioritas untuk diselesaikan sebab termasuk dalam prolegda dan menyangkut anggaran yang akan digunakan pada setiap tahun anggaran. skala prioritas dan efisiensi waktu pembentukan perda APBD tidak boleh mengabaikan kualitas perda tersebut. Paradigma baru pengelolaan keuangan daerah dilatarbelakangi oleh meningkatnya tuntutan masyarakat terhadap pengelolaan keuangan daerah atau publik secara transparan dan memenuhi prinsip akuntabilitas, disamping itu sistem, prosedur dan struktur APBD yang berlaku kurang mampu mendukung tuntutan perubahan sehingga perlu perencanaan APBD yang sistematis, terstruktur dan komprehensif. ${ }^{7}$

Pemerintahan daerah provinsi atau kabupaten/kota wajib meyebarluaskan Rancangan Peraturan Daerah. Sebagaimana diatur dalam Pasal 253 ayat (3) dan (4) UU No. 23 Tahun 2014 tentang Pemerintahan Daerah (UU Pemda) bahwa Rancangan Peraturan Daerah yang berasal dari Dewan Perwakilan Rakyat Daerah (DPRD) disebarluaskan oleh Sekretariat DPRD dan Rancangan Peraturan Daerah yang berasal dari Gubernur atau Bupati/Walikota disebarluaskan oleh Sekretaris Daerah. Dalam rangka akses informasi, Pemerintah Daerah wajib menyebar luaskan rancangan atau peraturan perundang-undangan tingkat daerah. Pandangan sosiologi hukum dan psikologi hukum, menganjurkan agar tahapan penyebarluasan (sosialisasi) perda harus dilakukan. Hal ini diperlukan agar terjadi komunikasi hukum antara perda dengan masyarakat yang harus patuh. Pola ini diperlukan agar terjadi internalisasi nilai atau norma yang diatur dalam perda sehingga ada tahap pemahaman dan kesadaran untuk mematuhinya. Nilai atau norma tersebut tentunya menyesuaikan dengan materi perda secara umum yaitu hal-hal yang berkaitan dengan rumah tangga daerah dan hal-hal yang berkaitan dengan organisasi pemerintah daerah. ${ }^{8}$

Penyebarluasan Undang-Undang (Promulgation of Law) merupakan hal yang berbeda dengan penerbitan Undang-Undang (Publication of Law). Pembedaan ini menurut Jimly Asshiddiqie, terdiri atas pengumuman yang bersifat resmi yang dikaitkan dengan saat mulai berlaku mengikatnya undangundang dan pengumuman untuk kepentingan sosialisasi kepada masyarakat luas. ${ }^{9}$ Sama halnya perda yang diumumkan secara resmi dan kepentingan sosialisasi ke masyarakat daerah. Namun, disini hanya akan dibahas pengumuman untuk keperluan sosialisasi saja karena objek perda APBD masih dalam bentuk Rancangan Peraturan Daerah APBD berarti pengumuman yang berbentuk penyebarluasan.

Rancangan Peraturan Daerah APBD (RAPBD) adalah sarana utama yang dapat menjembatani terlaksananya perda lainnya dalam suatu wilayah daerah. Semua Rancangan Peraturan Daerah diupayakan untuk disosialisasikan ke masyarakat sebab terkait partisipasi masyarakat untuk menentukan nasibnya sendiri. Sejalan dengan salah satu asas pembentukan peraturan perundangundangan yaitu azas keterbukaan yang artinya bahwa dalam proses pembentukan peraturan perundang-undangan mulai dari perencanaan, persiapan, penyusunan dan pembahasan bersifat transparan dan terbuka. Dengan demikian seluruh lapisan masyarakat mempunyai kesempatan seluasluasnya untuk memberikan masukan dalam proses pembuatan peraturan perundang-undangan. Oleh karena itu, pengaturan dan pelaksanaan aturan perundang-undangan terkait penyebarluasan perda khususnya perda APBD dapat dijadikan objek kajian demi terciptanya kualitas perda yang baik.

\section{HASIL DAN PEMBAHASAN}

Rancangan Peraturan daerah tentang Anggaran Pendapatan dan Belanja Daerah (RAPBD) dibentuk setiap tahun untuk memperlancar penyelenggaraan pemerintahan daerah. Transparansi dan partisipasi adalah dua azas penting yang menentukan kualitas perda baik sebelum maupun setelah perda ditetapkan. Salah satu tahapan pembentukan perda adalah tahap perancangan yaitu prosedur merancang naskah akademik beserta rancangan perda. Azas transparansi dan partisipasi seharusnya

7 Safriani, Andi. "Telaah terhadap Asas Akuntabilitas dalam Pengelolaan Keuangan Daerah." Jurisprudentie: Jurusan Ilmu Hukum Fakultas Syariah dan Hukum 4, no. 1 (2017): 9

${ }^{8}$ Rosjidi Ranggawidjaja, Pengantar Ilmu Perundang-Undangan Indonesia, (Bandung:Penerbit Mandar Maju, 1998), hlm. 23

9 Jimly Asshiddiqie, Perihal Undang-Undang, Jakarta: PT Raja Grafindo Persada, hlm.360 
diterapkan pada setiap tahap pembentukan perda. Namun, Penerapannya masih perlu dikaji lebih lanjut. Penyebarluasan (promulgation) perda sebagai salah satu tahapan pembentukan perda merupakan wujud transparansi yang berdampak pada partisipasi masyarakat.

Penegasan tahapan penyebarluasan produk peraturan daerah sangat penting bagi masyarakat yang menjadi objek pengaturan. Partisipasi dan keterbukaan produk aturan daerah dimaksudkan agar tidak terjadi aturan yang kontraproduktif dan tidak dikehendaki oleh masyarakat. Apalagi yang ingin dibentuk adalah peraturan daerah yang strategis seperti APBD tentunya akan menentukan kesejahteraan masyaakat di wilayah daerah. Kenyataannya, pembahasan RAPBD oleh pemerintah daerah dan DPRD terkadang mengabaikan transparansi atau keterbukaan ini. Masukan terhadap materi RAPBD berupa saran dan pendapat masyarakat hanya terwakili secara tidak langsung oleh wakil rakyat di DPRD tanpa ada mekanisme pemberian masukan yang jelas. Hal ini dapat dilihat pada tataran praktik dan kendala pengaturan dan pelaksanaanya.

\section{Praktik Penyebarluasan RAPBD oleh Pemerintah Daerah}

Penyebarluasan dimaksudkan agar khalayak ramai mengetahui Peraturan Perundang-undangan di daerah yang bersangkutan dan mengerti/ memahami isi serta maksud yang terkandung di dalamnya. Penyebarluasan dapat dilakukan melalui media elektronik, atau media cetak yang terbit di daerah yang bersangkutan serta media komunikasi langsung. Pasal 354 ayat (3) Undang-Undang 23 Tahun 2014 tentang Pemerintahan Daerah (UU Pemda) mengisyaratkan bahwa masyarakat berhak memberikan masukan secara lisan atau tertulis dalam pembentukan perda. Dalam hal masukan disampaikan secara lisan, maka yang bersangkutan dapat menyampaikan sendiri kecuali dalam hal masukan secara lisan disampaikan oleh kelompok masyarakat maka harus diwakilkan pada pimpinan kelompok tersebut.

Dalam UU No. 12 Tahun 2011 sebagaimana tetal diubah menjadi UU No. 15 Tahun 2019 tentang Pembentukan Peraturan Perundang-Undangan (UU P4) dalam penjelasan Pasal 30 dikemukakan bahwa Rancangan Peraturan Daerah disebarluaskan, misalnya melalui Televisi Republik Indonesia, Radio Republik Indonesia, Internet, media cetak seperti surat kabar, majalah, dan edaran di daerah yang bersangkutan, sehingga khalayak ramai mengetahui adanya Rancangan Peraturan Daerah yang sedang dibahas di DPRD yang bersangkutan. Dalam praktiknya di beberapa daerah ditemukan beberapa metode atau cara penyebarluasan RAPBD seperti tergambar pada Tabel 1.

Tabel 1. Metode Penyebarluasan RAPBD

\begin{tabular}{cccc}
\hline No & Provinsi/Kabupaten/Kota & Tahun & Metode Penyebarluasan \\
\hline 1 & Kabupaten Bantul & 2017 & $\begin{array}{c}\text { Internet } \\
\text { (Tanpa lampiran) } \\
\text { Internet } \\
\text { (tidak rinci) }\end{array}$ \\
3 & Provinsi Kalimantan Utara & 2020 & $\begin{array}{c}\text { Internet } \\
\text { (tanpa lampiran) }\end{array}$ \\
4 & Kabupaten Magelang & 2020 & $\begin{array}{c}\text { Internet } \\
\text { (tidak rinci) } \\
\text { Internet } \\
\text { (tidak rinci) }\end{array}$ \\
\hline
\end{tabular}

Pada umumnya masukan masyarakat terhadap pembentukan perda dilakukan secara lisan melalui kelompok masyarakat atau pemangku kepentingan. Penyebarluasan perda yang telah ditetapkan umumnya disebarluaskan melalui media on line yaitu web site pemerintah daerah. Praktik penyebarluasan perda tersebut berkorelasi dengan minimnya masukan masyarakat yang dilakukan secara lisan tanpa diwakili atau sendiri.

Contoh praktik penyebarluasan perda tersebut pada umumnya dilaksanakan pada saat perda telah ditetapkan. Adapun, pada saat perda masih pada tahap rancangan sangat minim pelaksanaannya. Padahal tahapan perencanaan merupakan kunci awal menuju keberhasilan pencapaian tujuan yang 
diinginkan. ${ }^{10}$ Perbedaan metode penyebarluasan tersebut karena aturan perundang-undangan yang mengatur tentang penyebarluasan rancangan perda juga berbeda dalam pengaturannya.

\section{Kendala Pengaturan Penyebarluasan RAPBD oleh Pemerintah Daerah}

Pemerintahan Daerah sebagai salah satu unsur penyelenggaraan pemerintahan berdasarkan Pasal 18 ayat (6) Undang-Undang Dasar Negara Republik Indonesia Tahun 1945, diberikan hak untuk menetapkan peraturan daerah dan peraturan-peraturan lain untuk melaksanakan otonomi dan tugas pembantuan. Sebagaimana peraturan perundang-undangan lain, Peraturan Daerah juga memerlukan tahapan atau proses dalam pembuatannya. Selain yang disebutkan dalam UU Nomor 12 Tahun 2011 tentang Pembentukan Peraturan Perundang-Undangan (UU P4) sebagaimana telah diubah menjadi UU Nomor 15 Tahun 2019 tentang P4. pembentukan peraturan daerah dipertegas dengan ketentuan dalam Pasal 237 ayat 2 Undang-Undang Nomor 23 Tahun 2014 tentang Pemerintahan Daerah (UU Pemda) yang menyebutkan bahwa "Pembentukan Perda mencakup tahapan perencanaan, penyusunan, pembahasan, penetapan, dan pengundangan yang berpedoman pada ketentuan peraturan perundangundangan". Keseluruhan tahapan sebagaimana yang diatur baik dalam UU P4 maupun UU Pemda, merupakan tahapan-tahapan yang secara formil tidak dapat diabaikan dalam proses pembuatan suatu peraturan daerah. Akan tetapi, tidak terdapat tahapan penyebarluasan perda pada kedua undangundang tersebut sehingga terkesan penyebarluasan bukan suatu kewajiban esensial dalam tahapan pembentukan perda.

Perencanaan pembentukan perda diatur pada Pasal......ayat (.) UU No. 15 Tahun 2019 tentang Pembentukan Pembentukan Peraturan Perundang-Undangan (UU P4) yaitu perda dimulai dari tahap perencanaan melalui program legislasi daerah (prolegda) dan UU No. 24 Tahun 2014 tentang Pemerintahan Daerah (UU Pemda) kemudian dijabarkan lebih lanjut melalui Peraturan Menteri Dalam Negeri Nomor 120 Tahun 2018 tentang Prosedur Penyusunan Produk Hukum Daerah dinyatakan bahwa penyusunan produk hukum daerah yang bersifat pengaturan dilaksanakan berdasarkan prolegda. Selanjutnya pada Permendagri tersebut diatur salah satu mekanisme pembentukan daerah yaitu penyebarluasan. Hal ini berbeda dengan UU P4 dan UU Pemda yang tidak memasukkan penyebarluasan sebagai bagian tahapan pembentukan melainkan memasukkannya pada setiap tahapan pembentukan secara in herent. Namun, tahap penyebarluasan ini diwajibkan pada saat perda sudah ditetapkan. Perbedaan tersebut secara rinci digambarkan pada Tabel 2.

Tabel 2. Perbedaan Pengaturan Penyebarluasan Perda

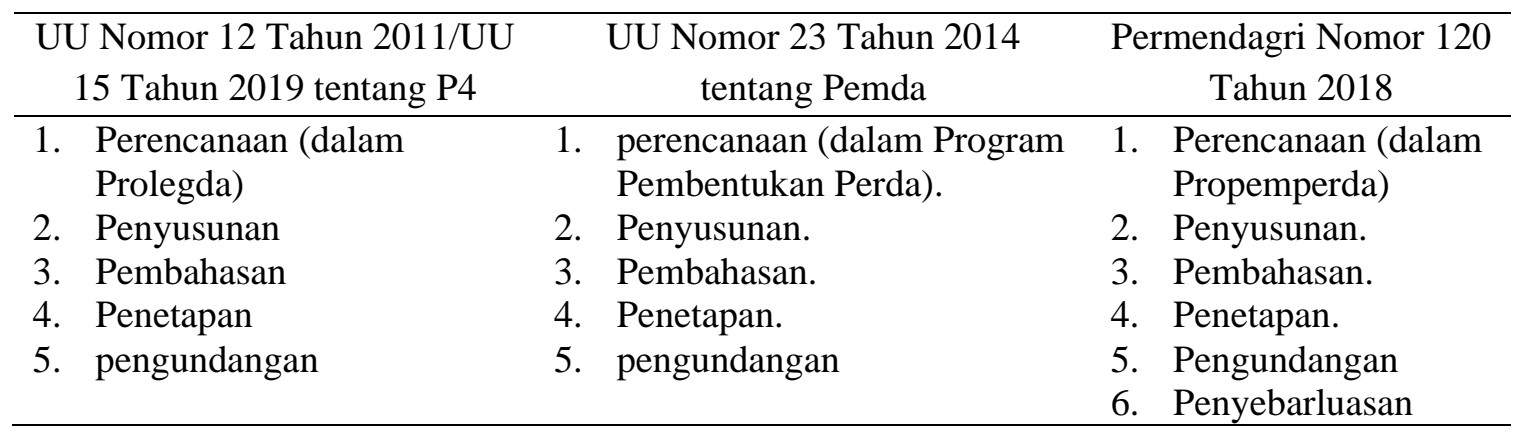

Dalam penyelenggaraan pemerintahan daerah setidak-tidaknya terdapat tiga perda yang strategis yaitu perda APBD, Rencana Tata Ruang dan Wilayah (RTRW), dan Pajak dan Retribusi. Ketiga perda tersebut seharusnya mendapat perlakukan khusus sebagaimana pada UU Pemda sebelumnya yaitu UU 32 Tahun 2004 tentang Pemda sebelum berganti menjadi UU 23 Tahun 2014 tentang Pemda. Dalam UU No. 32 Tahun 2004 tentang Pemda. mengatur tentang evaluasi terhadap ketiga jenis perda tersebut pada saat masih berbentuk rancangan perda. Hal ini lebih memungkinkan partisipasi masyarakat masuk kedalam tahapan perencanaan perda sehingga penyebarluasan rancangan perda dapat dilaksanakan. Ada teori fiksi hukum yang menganggap setiap orang dianggap tahu tentang keberadaan sutau aturan perundang-undangan. Penyebarluasan hanya diwajibkan dalam hal Perda yang telah

10 Eka N.A.M Sihombing, Problematika Penyusunan Program Pembentukan Peraturan Daerah (Problems on Forming Local Regulations Programs), Jurnal Legislasi Nasional Vol.13 No.03 September 2016, hlm. 289 
diundangkan dalam Lembaran Daerah dan Peraturan Kepala Daerah yang telah diundangkan dalam Berita Daerah oleh pemerintah daerah. Ketidaktegasan ini dapat ditafsirkan boleh dilakukan dan tidak dilakukan sehingga sangat sulit masyarakat melakukan pengawasan terhadap Rancangan Peraturan Daerah. Padahal telah diatur secara tegas di dalam UU Pemda bahwa masyarakat berhak memberikan masukan secara lisan atau tertulis dalam rangka penyiapan dan pembahasan rancangan Perda. Penyebarluasaan ini sangat berkaitan dengan partisipasi masyarakat karena pembentukan Perda pada dasarnya wajib memperhatikan prinsip akses informasi sebagaimana telah dijelaskan diatas dan akses partisipasi.

Partisipasi masyarakat ${ }^{11}$ pada tahap pembahasan di DPRD dapat dilakukan sesuai dengan Peraturan Tata Tertib DPRD. Dengan akses partisipasi memungkinkan masyarakat untuk menyampaikan aspirasi atau menyumbangkan pemikirannya terhadap suatu kebijakan yang akan diambil oleh Pemerintah Daerah. Terkait dengan RAPBD, tentunya prinsip-prinsip keuangan negara juga mengatur azas keterbukaan yang dijadikan salah satu azas anggaran. Secara yuridis formal dicantumkan pada Undang-Undang No. 17 Tahun 2003 tentang Keuangan Negara. (UU Keuangan Negara). Hanya saja, UU Keuangan Negara ini juga tidak dapat menjadi payung hukum untuk mewajibkan penyebarluasan perda pada tahap perencanaan. Oleh karena itu, belum ada satupun produk perundang-undangan yang dapat dijadikan rujukan untuk mewajibkan penyebarluasan rancangan perda khususnya perda strategis seperti perda APBD.

\section{SIMPULAN}

Produk peraturan daerah yang disebarluaskan pada tahap perencanaan dalam praktiknya relatif masih dilakukan secara lisan melalui perwakilan kelompok masyarakat atau pemangku kepentingan melalui media on line yaitu web site. Penyebarluasan ini terkendala pengaturan yang berbeda pada UU P4, UU Pemda, dan Permendagri terkait kewajiban penyebarluasan perda. Disamping itu, penyebarluasan yang diatur hanya pada saat setelah penetapan perda dalam bentuk penerbitan perda. Adapun, pada tahap perencanaan tidak diatur kewajiban penyebarluasannya. Hal ini berimbas pada pembentukan perda APBD sebagai perda yang strategis yang dibentuk setiap tahun. Apalagi UU Keuangan Negara juga tidak menegaskan kewajiban penyebarluasan perda APBD pada tahap perencanaan.

\section{DAFTAR PUSTAKA}

Jimly Asshidiqie, 2010. Perihal Undang-Undang. Jakarta: PT Raja Grafindo Persada

Eka N.A.M Sihombing, Problematika Penyusunan Program Pembentukan Peraturan Daerah (Problems on Forming Local Regulations Programs), Jurnal Legislasi Nasional Vol.13 No.03 September 2016

Indrati, Maria Farida, Proses Pembentukan Peraturan Perundang-undangan Pasca Amandemen UUD 1945, Majalah Hukum Nasional Jakarta, Nomor 1 Tahun 2005.

Priyanto, I Made Dedy, Kewenangan Gubernur dalam Pembatalan Perda Kabupaten Tabanan, Jurnal Advokasi FH Universitas Mahasaraswati Denpasar, Vol. I, Nomor 1, Tahun 2011.

Ronald M. M. Goni, Kewenagan Gubernur dalam Pembentukan Peraturan Daerah Sebagai Implementasi Pemberlakuan Otonomi Daerah, Jurnal Lex Administratum, Vol III, Nomor 4 Juni 2015.

Rosjidi Ranggawidjaja, 1998. Pengantar Ilmu Perundang-Undangan Indonesia, Bandung: Penerbit Mandar Maju

11 Pemerintah berkewajiban untuk melibatkan masyarakat dalam pembauatan peraturan daerah baik lisan dan tertulis. Lihat Indrati, Maria Farida, Proses Pembentukan Peraturan Perundang-undangan Pasca Amandemen UUD 1945, Majalah Hukum Nasional Jakarta, Nomor 1 Tahun 2005., hlm 98. 
Safriani, Andi. 2017. Telaah terhadap Asas Akuntabilitas dalam Pengelolaan Keuangan Daerah. Jurisprudentie: Jurusan Ilmu Hukum Fakultas Syariah dan Hukum Vol 4 No. 1

Sugiarto, Anton Hutomo, Arti Penting Program Legislasi Daerah Bagi Pencapaian Tujuan Otonimi Daerah, Jurnal Justicepro FH Universitas Yos Soedarso, Vol. 06, Nomor 2, Tahun 2018.

Sulaiman, King Faisal, 2017, Teori Peraturan dan Perundang-undangan dan Aspek Pengujiannya, Yogyakarta: Thafa Media.

Undang-Undang Dasar Negara Republik Indonesia Tahun 1945.

Undang-Undang Negara Republik Indonesia Nomor 12 Tahun 2011 tentang Pembentukan Peraturan Perundang-undangan.

Undang-Undang Negara Republik Indonesia Nomor 15 Tahun 2019 tentang Pembentukan Peraturan Perundang-Undangan.

Undang-Undang Negara Republik Indonesia Nomor 23 Tahun 2014 tentang Pemerintahan Daerah. 